\title{
Molecular and Electrophysiological Analyses of ATP2B4 Gene Variants in Bilateral Adrenal Hyperaldosteronism
}

\author{
Namita Ganesh Hattangady ${ }^{1,2}$ - Jessica Foster ${ }^{1}$. Antonio Marcondes Lerario ${ }^{1}$ - Daniela Ponce-Balbuena ${ }^{3}$. \\ Juilee Rege ${ }^{4} \cdot$ Silvia Monticone ${ }^{5} \cdot$ William E. Rainey ${ }^{1,4} \cdot$ Paolo Mulatero $^{4} \cdot$ Tobias Else $^{1}$ (D)
}

Received: 18 August 2019 / Accepted: 26 December 2019 / Published online: 30 January 2020

(C) Springer Science+Business Media, LLC, part of Springer Nature 2020

\begin{abstract}
Primary aldosteronism (PA) is the most common cause of secondary hypertension with a high prevalence among patients with resistant hypertension. Despite the recent discovery of somatic variants in aldosterone-producing adenoma (APA)associated PA, causes for PA due to bilateral aldosterone production (bilateral hyperaldosteronism; BHA) remain unknown. Herein, we identified rare gene variants in $A T P 2 B 4$, in a cohort of patients with BHA. ATP2B4 belongs to the same family of Ca-ATPases as $A T P 2 B 3$, which is involved in the pathogenesis of APA. Endogenous ATP2B4 expression was characterized in adrenal tissue, and the gene variants were functionally analyzed for effects on aldosterone synthase (CYP11B2) expression, steroid production in basal and agonist-stimulated conditions, and for changes in biophysical properties of channel properties. Knockdown of ATP2B4 in HAC15 exhibited reduced angiotensin II stimulation in one of four shRNA clones. Stable HAC15 cell lines with doxycycline (dox) - inducible wild-type and variant forms of $A T P 2 B 4$ - were generated, and dox-induced upregulation of $A T P 2 B 4$ mRNA and protein was confirmed. However, $A T P 2 B 4$ variants did not alter basal or agonist-stimulated CYP11B2 expression. Whole-cell recordings in HAC15 cells indicated robust endogenous $A T P 2 B 4$ conductance in native cells but reduced conductance with overexpressed WT and variant $A T P 2 B 4$. The previously defined PA-causing $A T P 2 B 3$ variant served as a positive control and exhibited elevated CYP11B2 mRNA. In conclusion, while this study did not confirm a pathogenic role for ATP2B4 variants in BHA, we describe the sequencing analysis for familial and sporadic BHA and outline a template for the thorough in vitro characterization of gene variants.
\end{abstract}

Keywords ATP2B4 · ATP2B3 · Ca-ATPases · Aldosterone $\cdot$ Primary aldosteronism $\cdot$ Doxycycline-inducible expression

Electronic supplementary material The online version of this article (https://doi.org/10.1007/s12672-019-00375-0) contains supplementary material, which is available to authorized users.

Tobias Else

telse@umich.edu

1 Department of Internal Medicine, Division of Metabolism, Endocrinology \& Diabetes, University of Michigan, 1150 West Medical Center Drive, Ann Arbor, MI 48109, USA

2 Clinical Research Division, Fred Hutchinson Cancer Research Center, Seattle, WA, USA

3 Center for Arrhythmia Research, University of Michigan, Ann Arbor, MI, USA

4 Department of Molecular and Integrative Physiology, University of Michigan, Ann Arbor, MI, USA

5 Department of Medical Sciences, Division of Internal Medicine and Hypertension, University of Torino, Via Genova 3,

10126 Torino, Italy

\section{Introduction}

Primary aldosteronism (PA) is the most common form of endocrine hypertension and characterized by renin-independent aldosterone excess. PA can be categorized into two main subtypes: bilateral and unilateral disease. PA is most often sporadic, but familial forms have been described. Over the past decade, next-generation sequencing (NGS) has identified somatic variants in aldosterone-producing adenoma (APA)-related PA. Thus far, NGS has identified several genetic variants in APAs, including KCNJ5, CACNA1H, CACNA1D, $A T P 2 B 3$, and ATP1A1 [1-14], as the underlying mechanism of aldosterone excess in APA. While somatic variants in these genes are found in up to $90 \%$ of all APAs, and therefore the majority of cases of unilateral aldosterone excess, germline variants in these or other genes are rare, explaining likely less than $5 \%$ of all cases with bilateral aldosterone excess $[15,16]$. 
The currently known germline variants cause a phenotype of bilateral disease, yet with significant variability in terms of severity, penetrance, age of onset, and associated symptoms. For instance, mutations in KCNJ5 account for up to $40 \%$ of APA-related PA [17, 18]. However, while the germline variant $K C N J 5^{G 15 I E}$ was associated with a phenotype of hypertension and negligible hyperplasia, a different germline variant at the same locus, $K C N J 5^{G 15 I R}$, exhibited a severe phenotype with massive hyperplasia, requiring bilateral adrenalectomy $[9$, 14]. Familial PA due to germline variants in CACNA1D causes a novel phenotype of PA associated with seizures and other neurological abnormalities [11]. Finally, most recently, whole-exome sequencing revealed germline variants in the inward rectifying chloride channel $C L C N 2$ in a subgroup of patients with PA [19, 20]. These patients present with bilateral hyperaldosteronism (BHA), and this genetic cause of BHA is classified as familial hyperaldosteronism type II (FH-II). However, the $C L C N 2$ variants have a low prevalence, and the cause for aldosterone excess in the majority BHA cases remains unexplained.

The vast majority of patients with BHA present as apparently sporadic disease. The bilateral nature of the disease, however, suggests a germline genetic predisposition as one putative causative mechanism. Unfortunately, the availability of tissue for detailed analyses is limited as these patients are usually treated medically. Therefore, analysis is largely restricted to germline variants in families with multiple affected members with PA or patients with apparently sporadic PA, with the assumption that pathogenic variants in genes are shared in this population. Using this approach, we identified rare variants in $A T P 2 B 4$, which encodes the calcium ATPase, isoform 4 (PMCA4).

PMCA4 belongs to the P-type family of calcium ATPases (PMCAs) [21-24] and is expressed on the cell surface in a variety of tissues, including the smooth muscle, liver, brain, heart, pancreas, and adrenal [25-30]. Within the adrenal, the $A T P 2 B 4$ gene is the highest expressed among all members of the calcium ATPase family [29]. PMCAs regulate intracellular calcium levels through their ability to hydrolyze one ATP molecule to actively pump a single intracellular calcium ion across the cell membrane. At low levels of cytoplasmic calcium, the calcium-calmodulin-binding domain interacts with other domains, blocking the access of calcium and/or ATP to the active site, thereby rendering the PMCA in an autoinhibited state [23-25, 31-33]. Increase in intracellular calcium levels causes the calcium-calmodulin complex to bind the carboxyl terminal, thus displacing it and enabling ATP-hydrolysis and pump activity. The ATP2B 4 gene is expressed as two transcript variants, $4 \mathrm{a}$ and $4 \mathrm{~b}$ (PMCA4a and PMCA4b, respectively; NM 001001396 and NM 001684, respectively) $[23-25,34,35]$. The PMCA4b variants have a larger calcium-calmodulin-binding domain, lower basal activity, and greater responsiveness to stimulation by calmodulin $[25,36]$. Altered interactions of PMCA4 in protein complexes or genetic mutations in $A T P 2 B 4$ or knockdown of the gene have been suggested to cause various pathologies including long QT syndrome, reduced sperm motility, and familial spastic paraplegia [23, 24, 37-39].

Since the ATP2B4 variants observed in our patients are localized to the calcium-calmodulin domain, we hypothesized a loss of function, causing constitutive self-inhibition of PMCA $4 \mathrm{~b}$ and accumulation of cytosolic calcium ions, resulting in elevated CYP11B2 expression and aldosterone production. We, therefore, analyzed these variants through an in vitro pipeline involving characterization of gene expression across tissues, analysis of effects of gene knockdown, as well as inducible overexpression of the gene variants on cellular mechanisms, LC-MS/MS measurement of steroids and electrophysiological characterization.

\section{Materials and Methods}

\section{Next-Generation Sequencing}

Informed consent was obtained from all individual participants included in the study. Patients were consented and analyzed through IRB-approved protocols (HUM0024461, HUM0151131). NGS was conducted in the UM sequencing core using the Illumina 2500. Paired-end reads (FASTQ file) were aligned to the hg19 assembly with Burrows-Wheeler alignment (BWA) 92. Then, picard tools were used for sorting and marking the duplicated reads in the resulting BAM files. Variant calling was performed with FreeBayes 93, and lowquality variants $(\mathrm{QUAL}<20)$ were discarded. Common variants (MAF > 20) were filtered out in our in-house database. The resulting VCF files were then annotated with ANNOVAR 94 and KGGseq 95. The final list of candidate genes was generated after excluding variants that are common in the population (MAF >1), non-coding and synonymous. From the resulting list of 502 variants, genes variants were selected if present only in the affected family members in each family, generating a list of 76 gene variants (Supplementary Table 1).

\section{Generation of Vectors}

The pMM2-hPMCA4b was a gift from John Penniston and Emanuel Strehler (Addgene plasmid \# 47759; http://n2t.net/ addgene:47759; RRID:Addgene 47,759). Wild-type PMCA4b was PCR amplified to include using restriction sites DraIII and XbaI at the $5^{\prime}$ and $3^{\prime}$ ends, respectively. The resultant amplicon was sub-cloned into the shuttle vector pENTR1A-GFP-N2 (FR1) [a gift from Eric Campeau \& Paul Kaufman (Addgene plasmid \# 19364; http://n2t.net/ addgene:19364; RRID:Addgene_19,364)] [40]. The variants of PMCA4b were generated by site-directed mutagenesis 
using the Q5® site-directed mutagenesis kit (New England Biolabs, Ipswich, MA). The resultant PMCA4b variants were inserted into the lentivector pCLX-pTF- R1-DEST-R2EBR65 [a gift from Patrick Salmon (Addgene plasmid \# 45952; http://n2t.net/addgene:45952; RRID:Addgene 45,952)] [41]. Lentiviruses $\left(\sim 1 \times 10^{6} \mathrm{TU} / \mathrm{mL}\right)$ were generated at the University of Michigan Biomedical Vector Core and used for transducing adrenal cells. Similarly, $A T P 2 B 3^{W T}$ and the previously described pathogenic variant $A T P 2 B 3^{\triangle L e u 425-V a l 426}$ (kindly donated by Dr. Sasha Bandulik) [29] were also cloned in to the pCLX-pTF- R1DEST-R2-EBR65 lentiviral system. These served as controls for the effect of the ATP2B family in adrenal cells.

\section{Cell Culture and Viral Transduction of Cell Lines}

The human adrenocortical carcinoma cell line, HAC15, was used as parental cells grown in DMEM-F12 containing 10\% CCS, $1 \%$ ITS, and antibiotics (PenStrep and gentamicin), as previously described. Transductions were performed as previously described [42]. HAC15 cells were transduced with lentiviruses at a multiplicity of infection of 3, as follows: 2 million cells were plated in a T-75 flask for $24 \mathrm{~h}$, after which they were incubated with fresh antibiotic-free growth media containing $10-\mu \mathrm{g} / \mathrm{mL}$ polybrene for $2 \mathrm{~h}$. Cells were then spinoculated (centrifuged) at $1000 \mathrm{rpm}$ with lentiviruses and antibiotic-free growth media with $8-\mu \mathrm{g} / \mathrm{mL}$ polybrene. After overnight incubation, the cells were recovered by the addition of twice the volume of growth media and incubated for additional $24 \mathrm{~h}$. At the end of $48 \mathrm{~h}$ from transduction, the cells were incubated in regular growth media containing $5-\mu \mathrm{g} /$ $\mathrm{mL}$ blasticidin (mammalian selection marker). A mixed population of blasticidin-selected HAC15 cells were used to analyze gene mutations. The generated cells carried doxycyclineinducible gene expression systems for $A T P 2 B 4^{W T}$, $A T P 2 B 4^{C 3152 A}, A T P 2 B 4^{C 31528 T}$, and ATP2B $4^{G 3346 A}$. For experiments, HAC15-dox-ATP2B4 cells (wild-type or variant cells) were plated in 24-well plates at a density of 200,000 cells/well until $60 \%$ confluence. After $48 \mathrm{~h}$, cells were starved in $0.1 \%$ CCS low serum media (LS) for $24 \mathrm{~h}$ and then treated with LS with/without doxycycline $(1 \mu \mathrm{g} / \mathrm{mL})$ for $72 \mathrm{~h}$ for maximal induction of the transgene. Agonists (10-nM Ang II and $18 \mathrm{mM} \mathrm{K}^{+}$) were introduced for the last $12 \mathrm{~h}$. For LCMS/MS measurement of steroids, cells were incubated with LS with/without doxycycline and agonists for $72 \mathrm{~h}$. Ang II was replenished every $24 \mathrm{~h}$ due.

For knockdown studies, HAC15-B2Luc cells (kindly donated by Dr. Celso Gomez-Sanchez) expressing a CYP11B2driven-secreted luciferase were cultured and treated with dox and agonists as described for gene expression studies. These cells have been successfully used for functional analysis of the $K C N J 5^{T 158 A}$ variant in adrenal cells [43]. HAC15-B2Luc cells were transduced with four different clones of short hairpin
RNA for ATP2B4 knockdown and selected with puromycin $(10 \mu \mathrm{g} / \mathrm{mL})$. As described elsewhere, $25 \mu \mathrm{L}$ of the media were analyzed for luciferase activity using coelentrazine[43].

For electrophysiological experiments, circular coverslips were coated with $50-\mu \mathrm{g} / \mathrm{mL}$ poly-D-lysine for $2 \mathrm{~h}$ at room temperature, followed by coating with $1-\mu \mathrm{g} / \mathrm{mL}$ laminin (overnight at $4{ }^{\circ} \mathrm{C}$ ). Coverslips were washed at least three times with $1 \mathrm{X}$ PBS and transferred to 24-well plates. At the time of patching, HAC15-dox-ATP2B4 cells incubated with doxycycline for $72 \mathrm{~h}$ were trypsinized and plated on the coated coverslips at a density of 100,000 cells/well in growth media with doxycycline and incubated for $1 \mathrm{~h}$ prior to patching.

\section{Steroid Quantitation by Liquid Chromatography/Tandem Mass Spectrometry (LC-MS/MS)}

A $150-\mu \mathrm{L}$ aliquot of media from HAC15-dox-ATP2B4 cells, along with $50-\mu \mathrm{L}$ internal standard of deuterated steroids, was deproteinated using acetonitrile as previously described [44]. Following deproteinization, extraction of steroids was performed using 1-mL methyl-t-butyl ether (MTBE). The organic phase was dried down and concentrated under nitrogen, reconstituted with $50 \mu \mathrm{L}$ of 1:1 methanol-deionized water, and transferred to a $0.25-\mathrm{mL}$ vial insert. The LC-MS/MS assay was performed as previously described [44].

\section{Electrophysiology}

Ion currents were recorded in whole-cell patch-clamp configuration using a MultiClamp 700B amplifier and Digidata 1440A digitizer (Molecular Devices, Sunnyvale, CA, USA) as described earlier [42]. Patch pipettes had resistances of 5-8 M $\Omega$ when filled with intracellular pipette solution and placed in extracellular solution. External solution containing 137-mM NaCl, 5-mM KCl, 5-mM glucose, 1$\mathrm{mM} \mathrm{MgCl} 2,1.2-\mathrm{mM} \mathrm{CaCl}_{2}$, and 5-mM HEPES (pH 7.4) was perfused through the system. The internal pipette solution contained 95-mM K-gluconate, $30-\mathrm{mM} \mathrm{KCl}, 4.8-\mathrm{mM}$ $\mathrm{Na}_{2} \mathrm{HPO}_{4}, 1.2-\mathrm{mM} \mathrm{NaH}{ }_{2} \mathrm{PO}_{4}, 5 \mathrm{mM}$ glucose, $2.38-\mathrm{mM}$ $\mathrm{MgCl}_{2}, 0.726-\mathrm{mM} \mathrm{CaCl} 2,1-\mathrm{mM}$ EGTA, and 3-mM ATP (pH 7.2). Data acquisition and analysis were performed using pCLAMP software (Molecular Devices, Sunnyvale, CA, USA). Normalization of current amplitudes to cell size was performed by dividing amplitudes by cell capacitance $(\mathrm{Cm})$ to generate current densities $(\mathrm{pA} / \mathrm{pF})[42]$.

\section{Immunofluorescence}

Slides with $5-\mu$ serial sections of the human adrenal cortex were deparaffinized. After antigen retrieval in $\mathrm{pH} 6$ citrate buffer and $\mathrm{pH} 9$ Tris buffer, respectively, the sections were incubated for $1 \mathrm{~h}$ in primary antibodies for CYP11B2 (mouse 
Table 1 Characteristics of the ATP2B4 variants

(A) Rare gene variants in $A T P 2 B 4$

\begin{tabular}{|c|c|c|c|c|c|}
\hline Gene Name & Nucleotide change & protein change & Frequency (EXAC) & Exon number & Transcript variant affected \\
\hline \multirow[t]{3}{*}{ АТР2B4 } & c.C3152A & p.T1051 N & 0.0015 & Exon 20 & PMCA4a, PMCA4b \\
\hline & $\mathrm{cC} 3158 \mathrm{~T}$ & p.S1053F & 0.0081 & Exon 20 & PMCA4a, PMCA4b \\
\hline & c.G3346A & p.E1116K & 0.0004 & Exon 21 & PMCA4b only \\
\hline \multicolumn{6}{|c|}{ (B). Clinical characteristic of BHA patients with rare $A T P 2 B 4$ variants } \\
\hline Parameters & Patient 1 & Patient 2 & Patient 3 & Patient 4 & \\
\hline ATP2B4 variant & c.C3152A & c.C3152A & c.G3346A & c.C3158T & \\
\hline Serum $\mathrm{K}^{+}(\mathrm{mEq} / \mathrm{L})$ & 3.2 & 4 & 3.4 & 3.4 & \\
\hline Aldosterone (ng/dL) & 42.2 & 20.4 & 47 & 23.7 & \\
\hline PRA (ng/mL/h) & 0.35 & 0.3 & 0.5 & 0.4 & \\
\hline ARR & 120.5 & 68 & 94 & 59.3 & \\
\hline Confirmatory test & 37 APR post captopril & $\begin{array}{l}10.9 \mathrm{ng} / \mathrm{dL} \text { aldosterone } \\
\text { post-saline load }\end{array}$ & $\begin{array}{l}11.2 \mathrm{ng} / \mathrm{dL} \text { aldosterone } \\
\text { post-saline load }\end{array}$ & $\begin{array}{l}12.1 \mathrm{ng} / \mathrm{dL} \text { aldosterone } \\
\text { post-saline load }\end{array}$ & \\
\hline AVS & BHA & $\mathrm{n} / \mathrm{a}$ & BHA & BHA & \\
\hline \multicolumn{6}{|l|}{ Imaging } \\
\hline Diagnosis & BHA & BHA & BHA & $\begin{array}{l}\text { Micronodule } 7 \mathrm{~mm} \\
\text { left adrenal }\end{array}$ & \\
\hline
\end{tabular}

monoclonal clone 41-17B; 1:100; kindly donated by Dr. Celso Gomez-Sanchez) and PMCA4b (mouse monoclonal clone JA9; Catalog\# MA1-914, Millipore; 1:100). After three successive washes in $1 \mathrm{X}$ PBS-0.5\% Tween (PBS-T), the sections were incubated Alexa Fluor ${ }^{\circledR} 647$ goat anti-mouse antibody (1:100) for $1 \mathrm{~h}$ and with 100-nM DAPI for 5 mins. Following washes in $1 \mathrm{X}$ PBS-T, coverslips were mounted using the ProLong ${ }^{\text {TM }}$ Gold Antifade Mountant without DAPI (Thermo Fisher Scientific). Sectioned treated with only secondary antibody served as negative controls. An $\mathrm{H}$ and E stained section of the adrenal was used to identify the zones.

\section{RNA Isolation and Gene Expression Assays}

RNA was extracted from tissue or cell lines using the RNeasy Plus Mini Kit (Qiagen, Hilden, Germany), following manufacturer's recommendations for on-column DNase treatment (RNase-free DNase Kit, Qiagen). Using the High-Capacity cDNA Reverse Transcription Kit, 20 ng of RNA was reversetranscribed (Thermo Fisher Scientific, Waltham, MA). Real-time quantitative PCR was performed for ATP2B4 (Hs00608066_m1, Thermo Fisher Scientific) and CYP11B2 and normalized to PPIA (Hs99999904_m1, Thermo Fisher Scientific), as previously described [42]. Relative quantification of the data was performed using the $2^{-\Delta \Delta \mathrm{Ct}}$ method.

\section{Statistical Analyses}

All experiments were performed a minimum of three times. Results were expressed as mean \pm S.E.M. Students t-tests or one-way ANOVA for multiple comparison was applied as required based on the specific groups being analyzed, using an alpha value of $5 \%$ and a power of $80 \%$.

\section{Results}

\section{Clinical Characteristics}

Patient 1 presented with hypertension (Table 1), a serum K of $3.2 \mathrm{mEq} / \mathrm{L}$, elevated aldosterone with suppressed renin (20.4 ng/dL aldosterone, plasma renin activity, i.e., PRA $0.35 \mathrm{ng} / \mathrm{mL} / \mathrm{h}$ ) and an aldosterone to renin ratio of 120.5 . Diagnosis of PA was confirmed by the captopril test and bilateral aldosterone excess by adrenal vein sampling. Patient 2, the brother to Patient 1, was also diagnosed with BHA. Whole-exome sequencing identified a heterozygous germline variant c. $3152 \mathrm{C}>\mathrm{A}(\mathrm{p} . \mathrm{T} 1051 \mathrm{~N})\left(A T P 2 B 4^{C 3152 A}\right)$ in both patients, but not in unaffected family members (Supplementary Figure, Panel 1A). Additional rare variants $\left(A T P 2 B 4^{\mathrm{C} 3158 \mathrm{~T}}\right.$ and $\left.A T P 2 B 4^{G 3346 A}\right)$ in ATP2B4 were identified in two patients with sporadic BHA (clinical details in Table 1). All variants occurred in the calmodulin (CaM)-binding domain of PMCA4. Additional characteristics of the observed variants including reported allelic frequencies and predicted effects of amino acid substitutions on protein function have been detailed in Supplementary Fig. 1, Panel B.

\section{ATP2B4 Expression in Different Tissues}

We initiated our studies by surveying for the differential expression of $A T P 2 B 4$ transcript levels across various 
Fig. 1 Expression of $A T P 2 B 4$ in tissues. (A) Real-time analyses of $A T P 2 B 4$ transcript variant 2 in adrenal tissues in comparison with various tissues. $* p<0.05$ versus pancreas. (B) Zonal expression of ATP $2 B 4$ mRNA across the human adrenal using laser capture microdissection. The three probes correspond to 205410_s_at, 212136_at, 212135 s at (top to bottom), which target the 3'UTR of both ATP2B4 transcripts. (C) Immunofluorescence for PMCA4b protein on serial sections of the human adrenal cortex (i) H\&E, (ii) negative control incubated only with secondary antibody and DAPI, and (iii, iv) expression of CYP11B2 and PMCA4b, respectively a

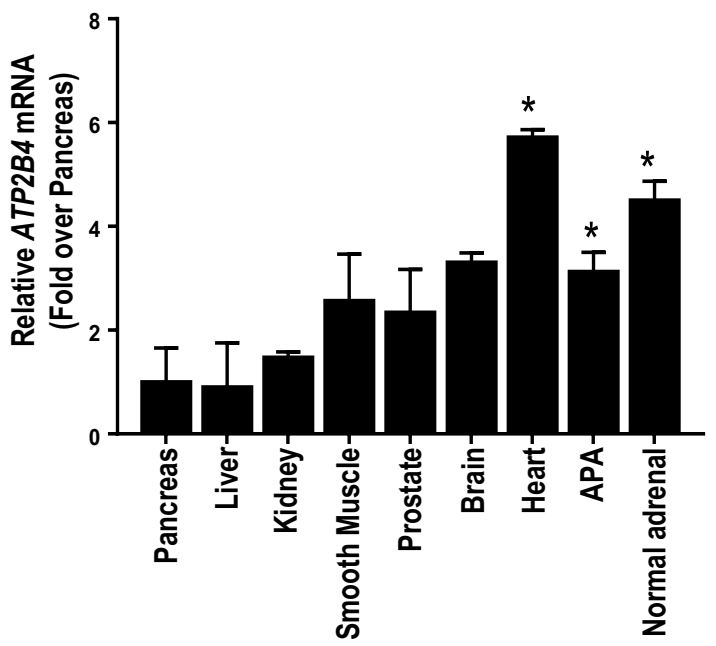

b

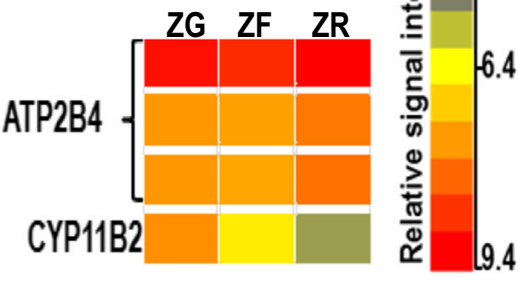

C

(i)
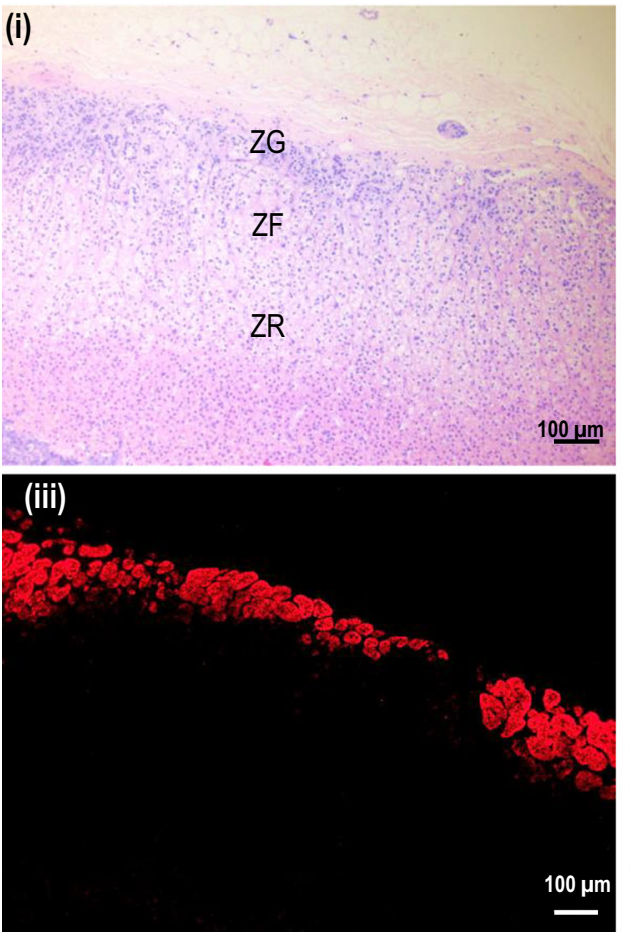

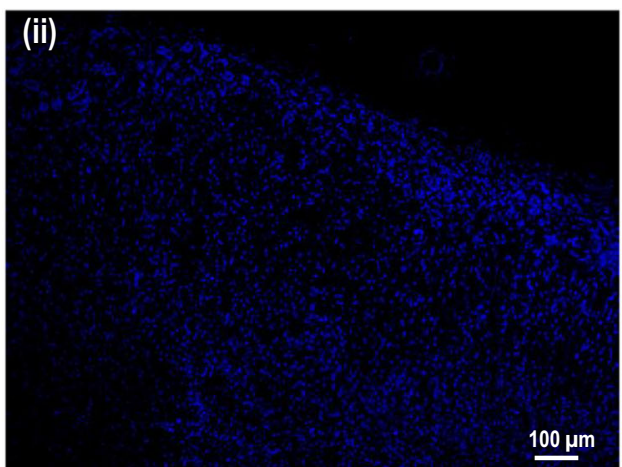

(iv)

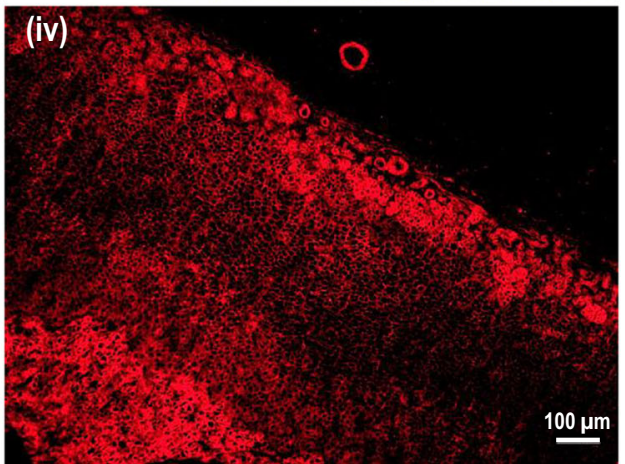

human tissues. Real-time quantitative PCR (RT-qPCR) analyses identified ATP2B 4 expression to be highest in the heart and healthy and pathological adrenal tissues (normal adrenals and APA) (Fig. 1, Panel A). Within the adrenal gland, the ATP2B 4 transcript was expressed throughout the cortex, without zone specificity (Fig. 1, Panel B). A similar pattern was observed for the ATP2B4 peptide, using immunofluorescence (Fig. 1, Panel C). Having confirmed the expression of ATP2B 4 in the adrenal and in aldosterone-producing adenomas, in vitro gene expression studies for functional analyses of the gene mutations were initiated.

\section{Effect of ATP2B4 Knockdown in HAC15 Cells}

Since the variants in $A T P 2 B 4$ are clustered near the calcium-calmodulin domain involved in ATPase activity, we initiated studies that replicate null mutations through knockdown of the endogenous $A T P 2 B 4$ transcripts. Four clones of short hairpin RNA (shRNA) lentiviruses targeting ATP2B4 were used to transduce the HAC15 cell line containing a CYP11B2 promoter-driven secreted Gaussian luciferase (HAC15-B2Luc) [43]. Non-targeted scrambled shRNA was used as a control. Real-time qPCR analyses confirmed significant, albeit not complete, 
knockdown of endogenous $A T P 2 B 4$ transcript and protein levels (Fig. 2, Panels $A$ and B). Knockdown of PMCA4b protein levels was also confirmed using western analysis. Among the four clones, only a single clone exhibited reduced angiotensin II (Ang II) stimulation of the CYP11B2 promoter. ATP2B4 knockdown did not affect basal or agonist (angiotensin II or $\mathrm{K}^{+}$-stimulated CYP11B2 promoter activity in the other clones (Fig. 2, Panel C).

\section{Effect of ATP2B4 Variants on Aldosterone Synthase (CYP11B2) Transcript Levels in HAC15 Cells}

To determine the effects of the ATP2B4 variants in adrenal cell physiology in normal and agonist-induced conditions, the adrenocortical cell line HAC15 was transduced with doxycycline (dox)-inducible lentiviruses for wild-type (WT) or observed rare variants of $A T P 2 B 4$. Dox treatment increased $A T P 2 B 4$ transcript levels by over 5-fold (Fig. 3, Panel A). Immunocytochemistry confirmed plasma membrane localization of the expressed protein (Fig. 3 Panel B). Expression of the variant ATP2B4 ${ }^{C 3152 A}$ did not increase basal CYP11B2 transcript levels. However, both WT and two of the rare variants $\left(A T P 2 B 4^{\mathrm{C} 3158 \mathrm{~T}}\right.$ and $A T P 2 B 4^{G 3346 A}$ ) did increase basal CYP11B2 levels (Fig. 3, Panel $C$ ). Further detailed analyses including stimulation by agonists Ang II and $\mathrm{K}$ suggested a lack of effect of any of the two of the rare ATP2B4 variants (Fig. 3, Panel D). On the other hand, cells expressing the ATP2B4 ${ }^{C 3152 A}$ variant displayed elevated CYP11B2 expression in K-stimulated conditions. As a positive control, dox-inducible wild-type ATP2B3 $\left(A T P 2 B 3^{W T}\right)$ and a previously described pathogenic variant containing the deletion Leu425-Val426 (ATP2B3 $3^{\triangle 425-426}$ ) [29] were expressed in HAC15 cells, using a similar strategy. This is the first ever study to develop and use a dox-inducible model for $A T P 2 B 3$ characterization. In this model system, incubation with dox induced ATP2B3 transcript levels by $\sim$ fourfold (Fig. 3, Panel E). The $A T P 2 B 3^{W T}$ variant decreased CYP11B2 transcript levels, in agreement with previous reports of reduced basal calcium levels in cells overexpressing the gene variant. Furthermore, $A T P 2 B 3^{\triangle 425-426}$ variant increased basal CYP11B2 levels by $\sim 15$-fold, a more potent effect than earlier reports using transient transfection [29]. The stimulatory effects of agonists were also enhanced in cells expressing $A T P 2 B 3^{\triangle 425-426}$ compared to $A T P 2 B 3^{W T}$ expressing adrenal cells (Fig. 3, Panels $F-H$ ).

\section{Effect of ATP2B4 Variants on Steroidogenesis}

Following the observations of the effect of the $A T P 2 B 4$ variants on $C Y P 11 B 2$ expression, we proceeded to evaluate downstream effects on steroid production in these cell lines. LC-MS/MS was used to measure the production of aldosterone and cortisol and that of hybrid steroids, 18-hydroxycortisol, and 18oxocortisol. Basal aldosterone levels were slightly elevated $(1.5 \pm 0.12$ fold, mean \pm S.E.M, $p \leq 0.05)$ in cells expressing
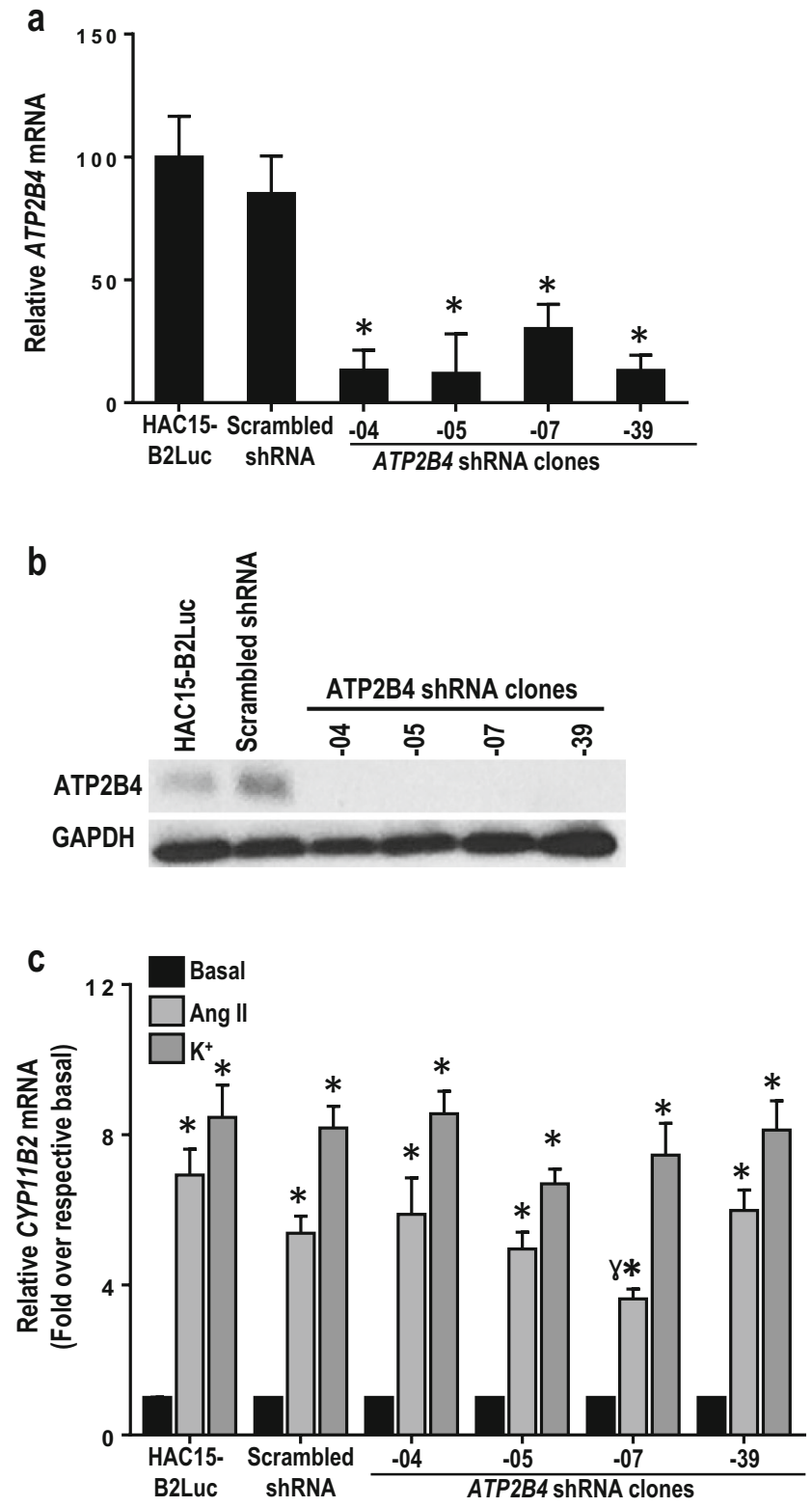

Fig. 2 Analysis of knockdown of $A T P 2 B 4$ in adrenal cells. (A, B) Realtime analysis demonstrating knockdown of $A T P 2 B 4 \mathrm{mRNA}$ and protein in four shRNA clones $(-04,-05,-07$, and -39$)$ and controls (HAC15B2Luc and scrambled shRNA). (C) Effect of ATP2B4 shRNA on agonist stimulation. ${ }^{*} p<0.05$ versus basal; ${ }^{\gamma} p<0.05$ versus HAC15 Ang II stimulation

$A T P 2 B 4^{W T}$, while they were unchanged for the variants $A T P 2 B 4^{C 3152 A}, A T P 2 B 4^{\mathrm{C} 3158 \mathrm{~T}}$, and ATP2B4 $4^{G 3346 A}$ (Fig. 4, Panel A). Agonists Ang II and $\mathrm{K}^{+}$, stimulated production of steroids (aldosterone, cortisol, 18-hydroxycortisol, and 18oxocortisol), when compared to basal, remained unchanged in $A T P 2 B 4^{W T}$ expressing cells or any of the cell lines expressing the rare ATP2B4 variants (Fig. 4, Panels $B-D$ ). Basal and agonist-induced production of upstream $\Delta 4$ steroids, including progesterone, 17-hydroxyprogesterone, and corticosterone, was also evaluated and found to be unaltered (data not shown). 
a

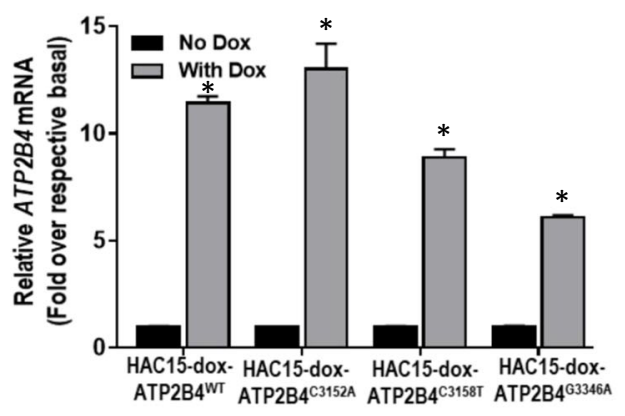

C

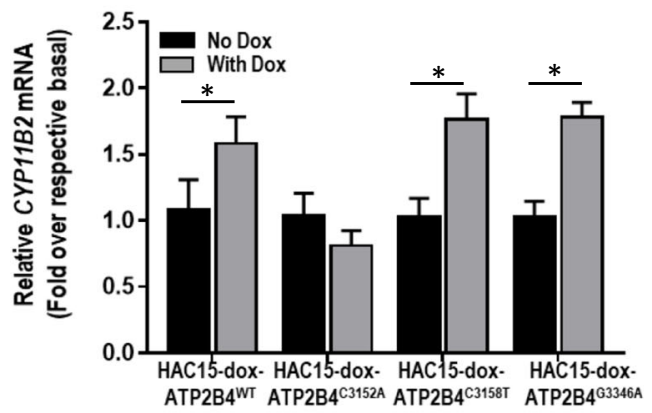

e

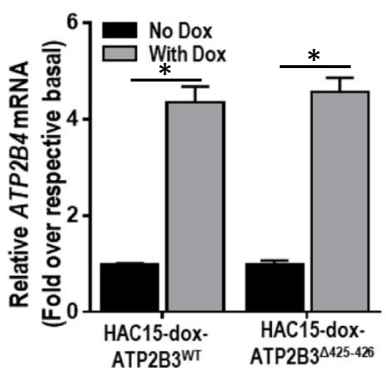

f

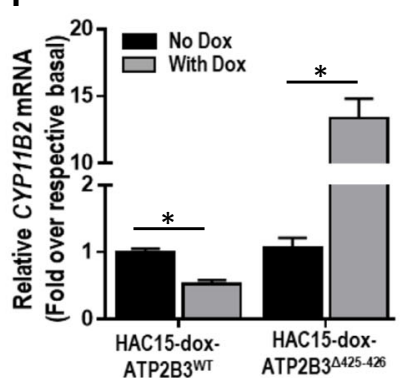

Fig. 3 Analysis of conditional expression of WT or variant $A T P 2 B 4$ in adrenal cells. (A, B) Real-time analysis demonstrating doxycyclineinducible expression of WT and variant $A T P 2 B 4$ forms $\left(A T P 2 B 4^{W T}\right.$ $C 3152 A / C 3158 T / G 3346 A)$ mRNA and protein in the HAC15 adrenal cell line. (C, D) Comparison of the effect of $A T P 2 B 4$ variants ( $72 \mathrm{~h}$ incubation with $1-\mu \mathrm{g} / \mathrm{mL}$ dox $)$ in basal and agonist-stimulated (12 h) conditions in

\section{Electrophysiological Analyses of ATP2B4 Variants}

Alongside of the effects of WT and variant forms of ATP2B4 on steroidogenic processes, changes in the biophysical properties of $A T P 2 B 4$ variants were also determined. A voltagestep protocol was used on non-transduced HAC15 cells and those expressing the ATP2B $4{ }^{\mathrm{WT}}$ or the ATP2B 4 variants (Fig. 5, Panels $A$ and B). The endogenous ATP2B4 current in $\mathrm{HAC} 15$ cells was very robust, ensuring a functional endogenous $A T P 2 B 4$ activity. HAC15 cells expressing increased ATP2B $4{ }^{\mathrm{WT}}$ had lower current density, similar to observations

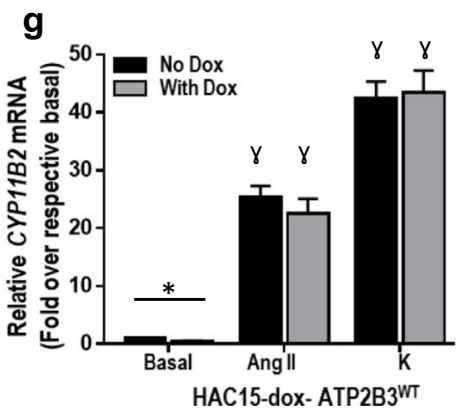

h

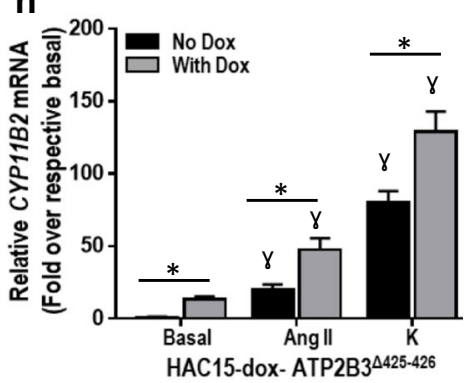

HAC15 cells. (E) Real-time analysis demonstrating doxycyclineinducible expression of WT and mutant ATP2B3, mRNA as positive controls. (F-H) Comparison of the effect of ATP2B3 ${ }^{\mathrm{WT}}$ and ATP2B $3^{\Delta 425-426}(72 \mathrm{~h}$ incubation with $1-\mu \mathrm{g} / \mathrm{mL}$ dox $)$ in basal and agonist-stimulated $(12 \mathrm{~h})$ conditions in HAC15 cells. $* p<0.05$ versus respective treatment without dox; ${ }^{\gamma} p<0.05$ versus respective basal

in cells expressing ATP2B $3^{\mathrm{WT}}$ [29]. Similarly, the density of the current rare variants was identical to that of ATP2B $4^{\mathrm{WT}}$. The resting membrane potential of adrenal cells expressing the variant forms of ATP2B4 was unchanged.

\section{Discussion}

Over the last decade, our understanding of the contribution of somatic genetic changes to APA-related PA has significantly increased. Research on the causes of BHA, however, has been 
a

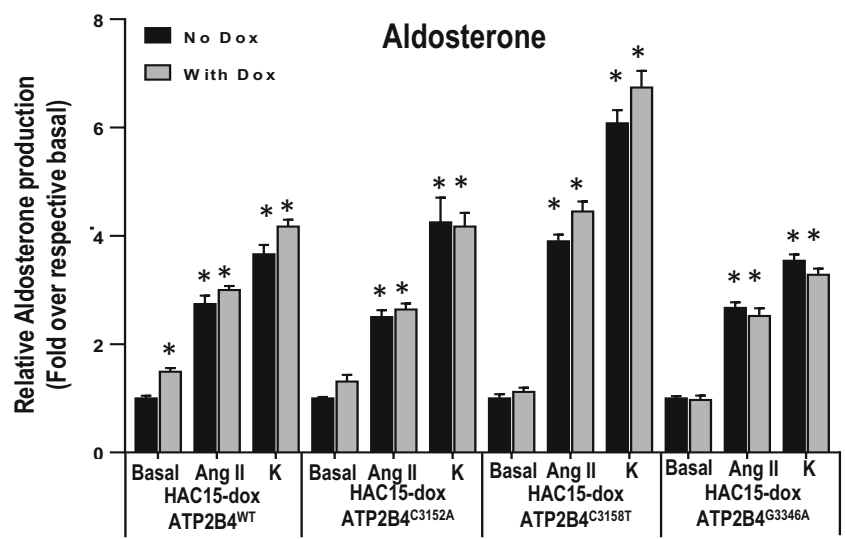

c

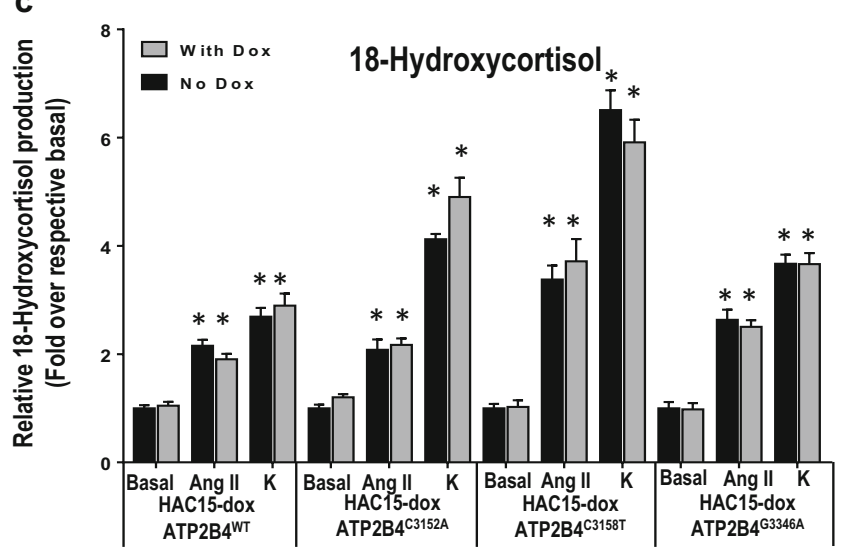

Fig. 4 Effect of WT and variant ATP2B4 forms on steroid production on HAC 15 cells. LC-MS/MS was used to determine the effect of elevated ATP2B4 variants (ATP2B4 $\left.4^{W T / C 3152 A / C 3158 T / G 3346 A}\right)$ on steroid production in $\mathrm{HAC} 15$ adrenal cells. Amount of steroid was calculated in $\mathrm{pg} / \mathrm{mL}$ and

stymied by the very limited tissue availability due to mainly pharmacologic treatment of bilateral disease.

Herein, we used exome sequencing of germline DNA obtained from patients with BHA in an attempt to identify potential pathogenic gene variants. We focused on three rare variants in $A T P 2 B 4$, which encodes the $\mathrm{Ca}^{2+}$ ATPase pump PMCA4. The mechanistic characterization of the variants involved the knockdown of endogenous $A T P 2 B 4$ as well as expression of wild-type and rare ATP2B4 variants in basal and agonist-stimulated conditions in the human adrenocortical carcinoma cell line (HAC15). The ATP2B $4^{C 3152 A}$ did not affect CYP11B2 transcript levels or the production of steroids, aldosterone, cortisol, 18-hydroxycortisol, or 18-oxocortisol, in basal conditions, although a minor increase in $\mathrm{K}^{+}$-stimulated aldosterone has been observed. The $A T P 2 B 4^{\mathrm{C} 3158 \mathrm{~T}}$ and $A T P 2 B 4^{G 3346 A}$ variants increased basal $C Y P 11 B 2$ mRNA levels, although not more than the $A T P 2 B 4^{W T}$ transgene itself and far less than an ATP2B3 variant observed in APAs that served as a positive control. No changes in current density were observed using electrophysiological analysis. Parallel analysis of a disease-causing variant in $A T P 2 B 3$ displayed b
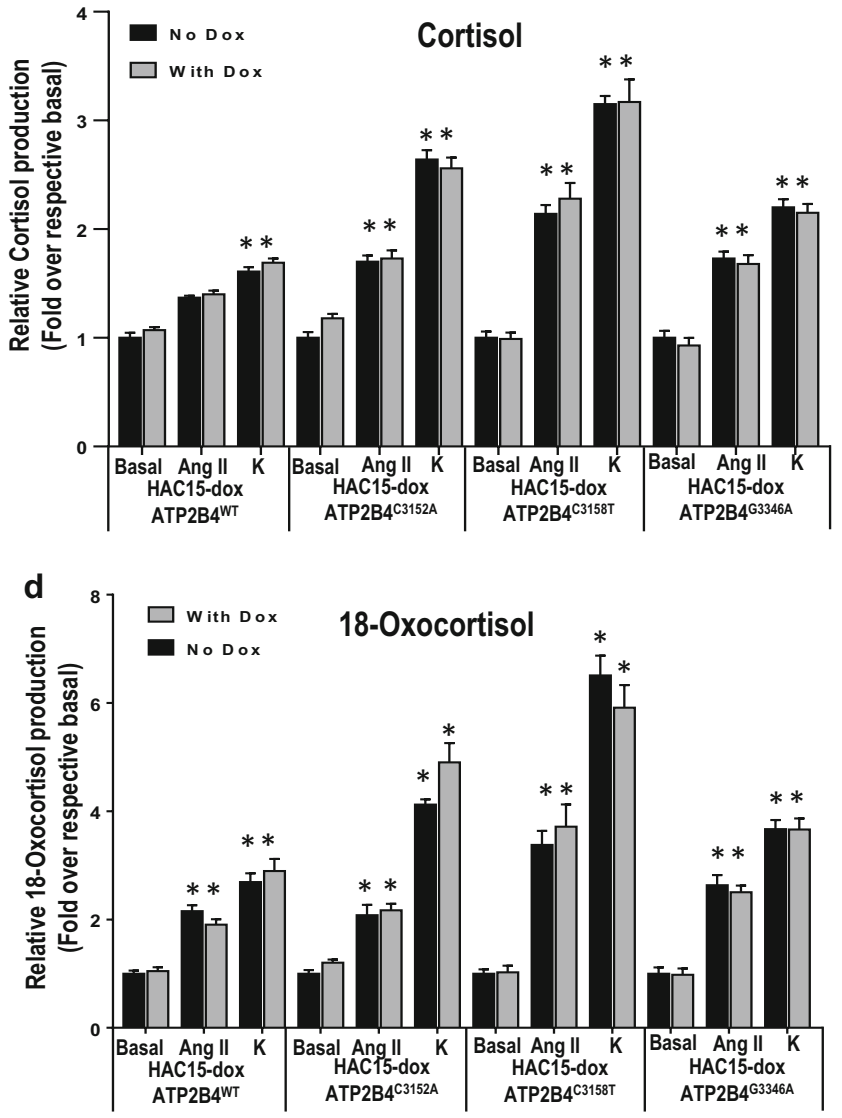

normalized to amount of protein per well. Means \pm S.E.M were calculated as fold over respective basals. $* p<0.05$ versus basals in respective cell lines

dramatic increases of CYP11B2 expression, making it unlikely that the subtle changes observed with $A T P 2 B 4$ variants are of pathophysiological relevance. Thus, overall, an overt pathogenic role with large increases in aldosterone production was excluded for the ATP2B4 variants.

We cannot, however, exclude the possibility that the $A T P 2 B 4$ variants act in conjunction with other genes or environmental factors that affect aldosterone production. Indeed, the challenge in finding new genetic causes of PA is that any new gene harboring potential pathogenic variants might be associated with low disease penetrance. An example of this phenomenon can be seen in the recent study investigating the role of several unique hereditary $C L C N 2$ gene variants, where at least one large kindred (CLCN2 $\left.{ }^{\mathrm{Arg} 172 \mathrm{Gln}}\right)$ showed incomplete penetrance [20]. Similarly, in vitro expression of several CLCN2 variants (p.Gly24Asp, p.Tyr26Asn, p.Met22Lys, p.Ser865Arg, p.Arg172Gln) showed great variation of their effects on CYP11B2 expression [19, 20]. Certainly, the incomplete penetrance could potentially be attributed, at least partially, to genomic and epigenomic changes acting as modifiers. 
a

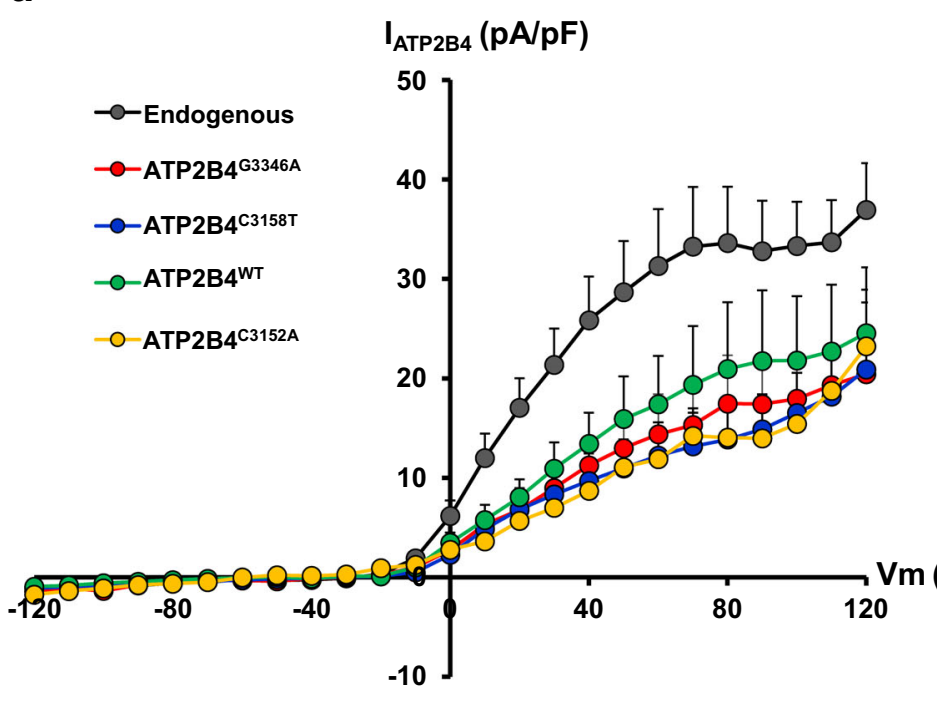

b

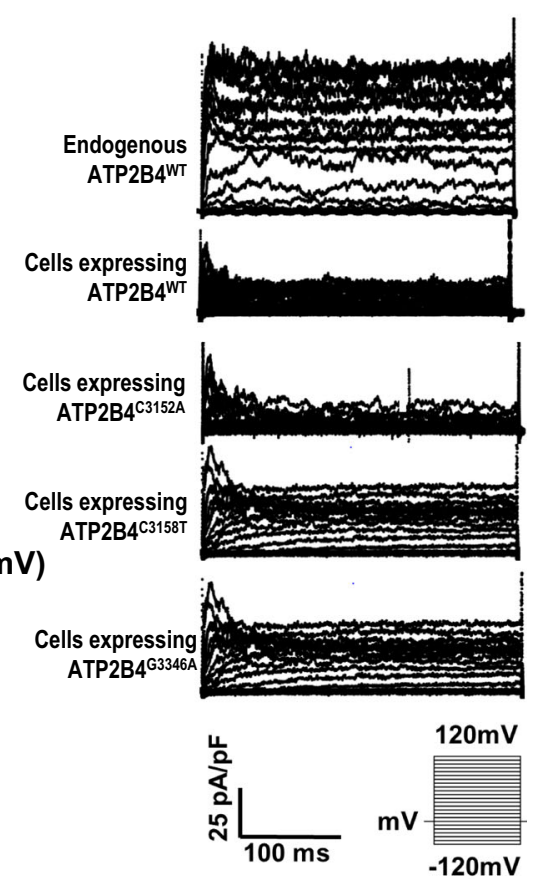

Fig. 5 Electrophysiological analyses of WT or variant ATP2B4 in HAC15 cells. IV plots (A) and traces (B) for HAC15 cells expressing endogenous ATP2B4, ATP2B $4^{W T}, A T P 2 B 4^{C 3152 A}, A T P 2 B 4^{C 3158 T}$, and

The hypothesis of a germline genetic predisposition to PA in BHA is based on the observation of bilateral reninindependent aldosterone production. However, there is also the possibility that a yet to be identified environmental or other pathogenic mechanism contributes to the phenomenon of BHA. To this extent, a recent study showed different rare variants in CACNA1D in different aldosterone-producing cell clusters found in the same adrenal gland from BHA patients [45]. It remains to be shown, whether these multiple somatic mutations could occur by chance or due to an underlying genetic predisposition.

In summary, while our study did not identify a pathogenic role of the ATP2B4 variants, we focused on developing a pipeline for the detailed analyses of gene variants. We successfully demonstrated an efficient lentiviral approach for tight dox-inducible gene expression and the assessment of rare gene variants. Certainly, this system exhibited a remarkable improvement in the effects of the PA-causing ATP2B3 mutation as compared to previous reports [29]. Further, we describe a thorough investigation of these variants including (1) characterization of gene expression across tissues, (2) knock-down analyses of an inactivating gene variant, (3) expression of the wild-type and rare gene variant to define their effects on CYP11B2 transcript levels and steroidogenesis by LC-MS/ MS, and (4) electrophysiological analyses of the biophysical properties of the variants in relation to the wild-type protein. Finally, we would like to emphasize the need to publish not
$A T P 2 B 4^{G 3346 A}$ ( $n=7-10$ for all variants). Internal and external solutions and protocols followed were as described in the Materials and Methods section

only proven pathogenic genetic causes of BHA but also analysis of rare genetic variants, for which experimental data argues against an involvement in the pathogenesis of the disease, even if it is simply to avoid a double effort in the scientific community.

Acknowledgments We would like to acknowledge Dr. Celso GomezSanchez for his advice on sub-cloning strategies and Dr. Sasha Bandulik for generously sharing expression vectors for ATP2B $3{ }^{\mathrm{WT}}$ and ATP2B3 $3^{\Delta 425-426}$.

Funding Information This work was supported by the American Heart Association Postdoctoral Fellowship (16POST29900003) awarded to Namita G. Hattangady and a grant from the NHLBI (5R01HL130106) awarded to Dr. Tobias Else.

\section{Compliance with Ethical Standards}

Conflict of Interest The authors declare that they have no conflict of interest.

\section{References}

1. Akerstrom T, Crona J, Verdugo AD, Starker LF, Cupisti K, Willenberg HS, Knoefel WT, Saeger W, Feller A, Ip J, Soon P, Anlauf M, Alesina PF, Schmid KW, Decaussin M, Levillain P, Wangberg B, Peix JL, Robinson B, Zedenius J, Backdahl M, Caramuta S, Iwen KA, Botling J, Stalberg P, Kraimps JL, Dralle H, Hellman P, Sidhu S, Westin G, Lehnert H, Walz MK, Akerstrom 
G, Carling T, Choi M, Lifton RP, Bjorklund P (2012) Comprehensive re-sequencing of adrenal aldosterone producing lesions reveal three somatic mutations near the KCNJ5 potassium channel selectivity filter. PLoS One 7(7):e41926

2. Azizan EA, Murthy M, Stowasser M, Gordon R, Kowalski B, Xu S, Brown MJ, O'Shaughnessy KM (2012) Somatic mutations affecting the selectivity filter of KCNJ5 are frequent in 2 large unselected collections of adrenal aldosteronomas. Hypertension 59(3): 587-591

3. Azizan EA, Poulsen H, Tuluc P, Zhou J, Clausen MV, Lieb A, Maniero C, Garg S, Bochukova EG, Zhao W, Shaikh LH, Brighton CA, Teo AE, Davenport AP, Dekkers T, Tops B, Kusters B, Ceral J, Yeo GS, Neogi SG, McFarlane I, Rosenfeld N, Marass F, Hadfield J, Margas W, Chaggar K, Solar M, Deinum J, Dolphin AC, Farooqi IS, Striessnig J, Nissen P, Brown MJ (2013) Somatic mutations in ATP1A1 and CACNA1D underlie a common subtype of adrenal hypertension. Nat Genet 45(9):10551060

4. Beuschlein F, Boulkroun S, Osswald A, Wieland T, Nielsen HN, Lichtenauer UD, Penton D, Schack VR, Amar L, Fischer E, Walther A, Tauber P, Schwarzmayr T, Diener S, Graf E, Allolio B, Samson-Couterie B, Benecke A, Quinkler M, Fallo F, Plouin PF, Mantero F, Meitinger T, Mulatero P, Jeunemaitre X, Warth R, Vilsen B, Zennaro MC, Strom TM, Reincke M (2013) Somatic mutations in ATP1A1 and ATP2B3 lead to aldosterone-producing adenomas and secondary hypertension. Nat Genet 45(4):440-4$444 \mathrm{e} 1-2$

5. Charmandari E, Sertedaki A, Kino T, Merakou C, Hoffman DA, Hatch MM, Hurt DE, Lin L, Xekouki P, Stratakis CA, Chrousos GP (2012) A novel point mutation in the KCNJ5 gene causing primary hyperaldosteronism and early-onset autosomal dominant hypertension. J Clin Endocrinol Metab 97(8):E1532-E1539

6. Choi M, Scholl UI, Yue P, Bjorklund P, Zhao B, Nelson-Williams C, Ji W, Cho Y, Patel A, Men CJ, Lolis E, Wisgerhof MV, Geller DS, Mane S, Hellman P, Westin G, Akerstrom G, Wang W, Carling T, Lifton RP (2011) K+ channel mutations in adrenal aldosteroneproducing adenomas and hereditary hypertension. Science 331(6018):768-772

7. Kuppusamy M, Caroccia B, Stindl J, Bandulik S, Lenzini L, Gioco F, Fishman V, Zanotti G, Gomez-Sanchez C, Bader M, Warth R, Rossi GP (2014) A novel KCNJ5-insT149 somatic mutation close to, but outside, the selectivity filter causes resistant hypertension by loss of selectivity for potassium. J Clin Endocrinol Metab 99(9): E1765-E1773

8. Monticone S, Hattangady NG, Penton D, Isales CM, Edwards MA, Williams TA, Sterner C, Warth R, Mulatero P, Rainey WE (2013) A novel Y152C KCNJ5 mutation responsible for familial hyperaldosteronism type III. J Clin Endocrinol Metab 98(11): E1861-E1865

9. Mulatero P, Tauber P, Zennaro MC, Monticone S, Lang K, Beuschlein F, Fischer E, Tizzani D, Pallauf A, Viola A, Amar L, Williams TA, Strom TM, Graf E, Bandulik S, Penton D, Plouin PF, Warth R, Allolio B, Jeunemaitre X, Veglio F, Reincke M (2012) KCNJ5 mutations in European families with nonglucocorticoid remediable familial hyperaldosteronism. Hypertension 59(2):235240

10. Murthy M, Azizan EA, Brown MJ, O'Shaughnessy KM (2012) Characterization of a novel somatic KCNJ5 mutation delI157 in an aldosterone-producing adenoma. J Hypertens 30(9):1827-1833

11. Scholl UI, Goh G, Stolting G, de Oliveira RC, Choi M, Overton JD, Fonseca AL, Korah R, Starker LF, Kunstman JW, Prasad ML, Hartung EA, Mauras N, Benson MR, Brady T, Shapiro JR, Loring E, Nelson-Williams C, Libutti SK, Mane S, Hellman P, Westin G, Akerstrom G, Bjorklund P, Carling T, Fahlke C, Hidalgo P, Lifton RP (2013) Somatic and germline CACNA1D calcium channel mutations in aldosterone-producing adenomas and primary aldosteronism. Nat Genet 45(9):1050-1054

12. Scholl UI, Stolting G, Nelson-Williams C, Vichot AA, Choi M, Loring E, Prasad ML, Goh G, Carling T, Juhlin CC, Quack I, Rump LC, Thiel A, Lande M, Frazier BG, Rasoulpour M, Bowlin DL, Sethna CB, Trachtman H, Fahlke C, Lifton RP (2015) Recurrent gain of function mutation in calcium channel CACNA1H causes early-onset hypertension with primary aldosteronism. Elife 4:e06315

13. Daniil G, Fernandes-Rosa FL, Chemin J, Blesneac I, Beltrand J, Polak M, Jeunemaitre X, Boulkroun S, Amar L, Strom TM, Lory P, Zennaro MC (2016) CACNA1H mutations are associated with different forms of primary Aldosteronism. EBioMedicine 13:225-236

14. Scholl UI, Nelson-Williams C, Yue P, Grekin R, Wyatt RJ, Dillon MJ, Couch R, Hammer LK, Harley FL, Farhi A, Wang WH, Lifton RP (2012) Hypertension with or without adrenal hyperplasia due to different inherited mutations in the potassium channel KCNJ5. Proc Natl Acad Sci U S A 109(7):2533-2538

15. Nanba K, Omata K, Else T, Beck PCC, Nanba AT, Turcu AF, Miller BS, Giordano TJ, Tomlins SA, Rainey WE (2018) Targeted Molecular characterization of aldosterone-producing adenomas in white Americans. J Clin Endocrinol Metab 103(10):3869-3876

16. Nanba K, Omata K, Gomez-Sanchez CE, Stratakis CA, Demidowich AP, Suzuki M, Thompson LDR, Cohen DL, Luther JM, Gellert L, Vaidya A, Barletta JA, Else T, Giordano TJ, Tomlins SA, Rainey WE (2019) Genetic characteristics of aldosteroneproducing adenomas in blacks. Hypertension 73(4):885-892

17. Fernandes-Rosa FL, Williams TA, Riester A, Steichen O, Beuschlein F, Boulkroun S, Strom TM, Monticone S, Amar L, Meatchi T, Mantero F, Cicala MV, Quinkler M, Fallo F, Allolio B, Bernini G, Maccario M, Giacchetti G, Jeunemaitre X, Mulatero P, Reincke M, Zennaro MC (2014) Genetic spectrum and clinical correlates of somatic mutations in aldosteroneproducing adenoma. Hypertension 64(2):354-361

18. Monticone S, Hattangady NG, Nishimoto K, Mantero F, Rubin B, Cicala MV, Pezzani R, Auchus RJ, Ghayee HK, Shibata H, Kurihara I, Williams TA, Giri JG, Bollag RJ, Edwards MA, Isales CM, Rainey WE (2012) Effect of KCNJ5 mutations on gene expression in aldosterone-producing adenomas and adrenocortical cells. J Clin Endocrinol Metab 97(8):E1567-E1572

19. Fernandes-Rosa FL, Daniil G, Orozco IJ, Goppner C, El Zein R, Jain V, Boulkroun S, Jeunemaitre X, Amar L, Lefebvre H, Schwarzmayr T, Strom TM, Jentsch TJ, Zennaro MC (2018) A gain-of-function mutation in the CLCN2 chloride channel gene causes primary aldosteronism. Nat Genet 50(3):355-361

20. Scholl UI, Stolting G, Schewe J, Thiel A, Tan H, Nelson-Williams C, Vichot AA, Jin SC, Loring E, Untiet V, Yoo T, Choi J, Xu S, Wu A, Kirchner M, Mertins P, Rump LC, Onder AM, Gamble C, McKenney D, Lash RW, Jones DP, Chune G, Gagliardi P, Choi M, Gordon R, Stowasser M, Fahlke C, Lifton RP (2018) CLCN2 chloride channel mutations in familial hyperaldosteronism type II. Nat Genet 50(3):349-354

21. Pedersen PLCE (1987b) Ion motive ATPases. II. Energy coupling and work output. Trends Biochem Sci 12(C):186-189

22. Pedersen PLCE (1987a) Ion motive ATPases. I. Ubiquity, properties, and significance to cell function. Trends Biochem Sci 12:146150

23. Brini M, Carafoli E (2009) Calcium pumps in health and disease. Physiol Rev 89(4):1341-1378

24. Oceandy D, Mohamed TM, Cartwright EJ, Neyses L (2011) Local signals with global impacts and clinical implications: lessons from the plasma membrane calcium pump (PMCA4). Biochim Biophys Acta 1813(5):974-978

25. Strehler EE, Zacharias DA (2001) Role of alternative splicing in generating isoform diversity among plasma membrane calcium pumps. Physiol Rev 81(1):21-50 
26. Brandt P, Neve RL, Kammesheidt A, Rhoads RE, Vanaman TC (1992) Analysis of the tissue-specific distribution of mRNAs encoding the plasma membrane calcium-pumping ATPases and characterization of an alternately spliced form of PMCA4 at the cDNA and genomic levels. J Biol Chem 267(7):4376-4385

27. Stauffer TP, Hilfiker H, Carafoli E, Strehler EE (1993) Quantitative analysis of alternative splicing options of human plasma membrane calcium pump genes. J Biol Chem 268(34):25993-26003

28. Kolodecik TR, Reed AM, Date K, Shugrue CA, Patel V, Chung SL, Desir GV, Gorelick FS (2017) The serum protein renalase reduces injury in experimental pancreatitis. J Biol Chem 292(51):2104721059

29. Tauber P, Aichinger B, Christ C, Stindl J, Rhayem Y, Beuschlein F, Warth R, Bandulik S (2016) Cellular pathophysiology of an adrenal adenoma-associated mutant of the plasma membrane $\mathrm{Ca}(2+)$ ATPase ATP2B3. Endocrinology 157(6):2489-2499

30. Howard A, Barley NF, Legon S, Walters JR (1994) Plasmamembrane calcium-pump isoforms in human and rat liver. Biochem J 303(Pt 1):275-279

31. Enyedi A, Verma AK, Heim R, Adamo HP, Filoteo AG, Strehler EE, Penniston JT (1994) The Ca2+ affinity of the plasma membrane $\mathrm{Ca} 2+$ pump is controlled by alternative splicing. J Biol Chem 269(1):41-43

32. Falchetto R, Vorherr T, Brunner J, Carafoli E (1991) The plasma membrane $\mathrm{Ca} 2+$ pump contains a site that interacts with its calmodulin-binding domain. J Biol Chem 266(5):2930-2936

33. Falchetto R, Vorherr T, Carafoli E (1992) The calmodulin-binding site of the plasma membrane Ca2+ pump interacts with the transduction domain of the enzyme. Protein Sci 1(12):1613-1621

34. Olson S, Wang MG, Carafoli E, Strehler EE, McBride OW (1991) Localization of two genes encoding plasma membrane Ca2(+)transporting ATPases to human chromosomes 1q25-32 and 12q21-23. Genomics 9(4):629-641

35. Keeton TP, Shull GE (1995) Primary structure of rat plasma membrane $\mathrm{Ca}(2+)$-ATPase isoform 4 and analysis of alternative splicing patterns at splice site a. Biochem J 306(Pt 3):779-785

36. Padanyi R, Paszty K, Penheiter AR, Filoteo AG, Penniston JT, Enyedi A (2003) Intramolecular interactions of the regulatory region with the catalytic core in the plasma membrane calcium pump. J Biol Chem 278(37):35798-35804
37. Withers S, Cartwright EJ, Neyses L (2006) Sperm phenotype of mice carrying a gene deletion for the plasma membrane calcium/ calmodulin dependent ATPase 4. Mol Cell Endocrinol 250(1-2): 93-97

38. Ho PW, Pang SY, Li M, Tse ZH, Kung MH, Sham PC, Ho SL (2015) PMCA4 (ATP2B4) mutation in familial spastic paraplegia causes delay in intracellular calcium extrusion. Brain Behav 5(4): e00321

39. Li M, Ho PW, Pang SY, Tse ZH, Kung MH, Sham PC, Ho SL (2014) PMCA4 (ATP2B4) mutation in familial spastic paraplegia. PLoS One 9(8):e104790

40. Campeau E, Ruhl VE, Rodier F, Smith CL, Rahmberg BL, Fuss JO, Campisi J, Yaswen P, Cooper PK, Kaufman PD (2009) A versatile viral system for expression and depletion of proteins in mammalian cells. PLoS One 4(8):e6529

41. Giry-Laterriere M, Cherpin O, Kim YS, Jensen J, Salmon P (2011) Polyswitch lentivectors: "all-in-one" lentiviral vectors for druginducible gene expression, live selection, and recombination cloning. Hum Gene Ther 22(10):1255-1267

42. Hattangady NG, Karashima S, Yuan L, Ponce-Balbuena D, Jalife J, Gomez-Sanchez CE, Auchus RJ, Rainey WE, Else T (2016) Mutated KCNJ5 activates the acute and chronic regulatory steps in aldosterone production. J Mol Endocrinol 57(1):1-11

43. Oki K, Plonczynski MW, Luis Lam M, Gomez-Sanchez EP, Gomez-Sanchez CE (2012) Potassium channel mutant KCNJ5 T158A expression in HAC-15 cells increases aldosterone synthesis. Endocrinology 153(4):1774-1782

44. Rege J, Nishimoto HK, Nishimoto K, Rodgers RJ, Auchus RJ, Rainey WE (2015) Bone morphogenetic Protein-4 (BMP4): a paracrine regulator of human adrenal C19 steroid synthesis. Endocrinology 156(7):2530-2540

45. Omata K, Satoh F, Morimoto R, Ito S, Yamazaki Y, Nakamura Y, Anand SK, Guo Z, Stowasser M, Sasano H, Tomlins SA, Rainey WE (2018) Cellular and genetic causes of idiopathic Hyperaldosteronism. Hypertension 72(4):874-880

Publisher's Note Springer Nature remains neutral with regard to jurisdictional claims in published maps and institutional affiliations. 